\title{
RECOMMENDATIONS FOR MONITORING HEARING IN CHILDREN USING A RISK FACTOR REGISTRY
}

\author{
Rachael Beswick ${ }^{1,2}$, Carlie Driscoll ${ }^{1}$, Joseph Kei ${ }^{1}$, Shirley Glennon ${ }^{2}$ \\ ${ }^{1}$ School of Health and Rehabilitation Sciences, The University of Queensland, Brisbane, Queensland, Australia \\ ${ }^{2}$ Clinical and State-wide Services, Queensland Health, Queensland Government, Queensland, Australia
}

Financial support: Nil.

Corresponding author: Rachael Beswick, Level 13, Block 7, Cnr Herston \& Bowen Bridge Rds, Herston, Queensland 4029, Australia, e-mail: Rachael_Beswick@health.qld.gov.au

\begin{abstract}
Background: The Joint Committee on Infant Hearing (JCIH) of the American Academy of Pediatrics recommends targeted surveillance of at-risk infants using a risk factor registry, in conjunction with parent and/or professional monitoring to detect hearing loss that develops after newborn hearing screening. However, criticisms of these recommendations are emerging as targeted surveillance programs are costly, resource intensive, have poor follow-up rates, and lack evidence of best practice. The purpose of the current paper is to provide recommendations for risk factor registries incorporated within targeted surveillance programs.
\end{abstract}

Methods: Recommendations provided in this document were developed by combining the results of previous research, done with a systematic review of the literature, together with a comprehensive evaluation of a targeted surveillance program in Queensland, Australia.

Results: Recommendations are as follows. Children with the risk factors of family history or craniofacial anomalies should have their hearing monitored, whereas children with the risk factor of low birth weight should not. Children with the risk factors of syndrome or prolonged ventilation should potentially have their hearing monitored; however, the evidence is not definitive. Equally, children with bacterial meningitis, hyperbilirubinemia, or professional concern as a risk factor may potentially not need their hearing monitored, but again the evidence is not definitive. For the risk factors of severe asphyxia and congenital infection, the evidence was inconclusive and/or conflicting, so no recommendations are made.

Conclusion: More research is needed to further inform evidence-based clinical policy recommendations for hearing loss detection in early childhood.

Keywords: surveillance $\bullet$ risk factors $\bullet$ at-risk $\bullet$ monitoring $\bullet$ postnatal hearing loss $\bullet$ children

Abbreviations: ABR - auditory brainstem response; CMV - cytomegalovirus; DPOAEs - distortion product otoacoustic emissions; ECMO - extracorporeal membrane oxygenation; HIE - hypoxic ischemic encephalopathy; HIV - human immunodeficiency virus; HVDT - health visitor distraction test; JCIH - Joint Committee on Infant Hearing; LBW - low birth weight; NHMRC - National Health and Medical Research Council (Australia); PPHN - persistent pulmonary hypertension of the newborn; TEOAEs - transient evoked otoacoustic emissions; UNHS - universal newborn hearing screening; VRA - visual reinforcement audiometry.

\section{RECOMENDACIONES PARA SEGUIMIENTO DE AUDICIÓN EN NIÑOS UTILIZANDO UN REGISTRO DE FACTORES DE RIESGO}

\section{Extracto}

Antecedentes: El Comité Conjunto sobre Audición Infantil (the Joint Committee on Infant Hearing - JCIH) de la Academia Americana de Pediatría (the American Academy of Pediatrics) recomienda una vigilancia específica de los niños en situación de riesgo utilizando un registro de factores de riesgo, junto con supervisión por los padres y/o supervisión profesional para detectar la pérdida de audición que se desarrolla después de screening auditivo neonatal. Sin embargo, aparecen críticas de estas recomendaciones, ya que los programas específicos de vigilancia son costosos, requieren muchos recursos, tienen bajas tasas de seguimiento y carecen de evidencia de buenas prácticas. El propósito del presente trabajo es proporcionar recomendaciones para los registros de los factores de riesgo incorporadas en los programas de vigilancia específicos.

Métodos: Las recomendaciones proporcionadas en este documento se han elaborado mediante la combinación de los resultados de la investigación anterior, realizada con una revisión sistemática de la literatura, con una evaluación integral de un programa de vigilancia específico realizado en Queensland, Australia. 
Resultados: Las recomendaciones son las siguientes: Los niños con los factores de riesgo de la historia familiar o anomalías craneofaciales requieren seguimiento de su audiencia, mientras que los niños con el factor de riesgo de bajo peso al nacer no lo requieren. Los niños con los factores de riesgo de ventilación prolongada o de síndrome potencialmente requieren seguimiento de su audiencia, sin embargo, las pruebas no son definitivas. Igualmente, en el caso de factores de riesgo siendo meningitis bacteriana, hiperbilirrubinemia o preocupación profesional, los niños potencialmente pueden no necesitar seguimiento de su audiencia, pero en este caso las pruebas tampoco son definitivas. Para los factores de riesgo de asfixia severa e infección congénita, las pruebas no fueron concluyentes y/o fueron contradictorias, por lo que no se hacen recomendaciones.

Conclusión: Se necesita más investigación para elaborar recomendaciones para políticas clínicas basadas en pruebas para detección de pérdida de audición en la infancia temprana.

Palabras claves: vigilancia • factores de riesgo • seguimiento • pérdida de audición postnatal • niños

Abreviaturas: ABR - respuesta auditiva del tronco encefálico; CMV - citomegalovirus; DPOAE - emisiones otoacústicas por productos de distorsión; ECMO - oxigenación por membrana extracorpórea; HIE - encefalopatía hipóxico-isquémica; VIH virus de la inmunodeficiencia humana; HVDT - test de distracción por visitador médico; JCIH - Comité Conjunto sobre Audición Infantil; LBW - bajo peso al nacer; NHMRC - Consejo Nacional de Salud e Investigaciones Médicas (Australia); PPHN - hipertensión pulmonar persistente del recién nacido; TEOAEs - otoemisiones acústicas evocadas transitorias; UNHS - screening auditivo neonatal universal; VRA - audiometría de refuerzo visual.

\section{РЕКОМЕНДАЦИИ ПО ПРОВЕРКЕ СЛУХА У ДЕТЕЙ С ИСПОЛЬЗОВАНИЕМ РЕГИСТРАЦИИ ФАКТОРОВ РИСКА}

\section{Резюме}

Предпосылки: Комитет по проблемам слуха у грудных детей американской академии педиатров рекомендует целенаправленное наблюдение новорожденных из группы риска с помощью регистрации факторов риска, в сочетании с наблюдением родителей и/или профессионалистов, чтобы выявлять потерю слуха, которая развивается после всеобщего тестирования слуха новорожденных. Однако, появляется критика этих рекомендаций, подчеркивующая, что программы целенаправленного наблюдения дорогие, требующие больших средств, имеют низкий предел проверки исполнения, и не имеется доказательств из самой лучшей практики. Цель этой исследовательской работы - предоставить рекомендации по регистрации факторов риска, внедренные в программы целенаправленного наблюдения.

Методы: Предоставленные в этой работе рекомендации разработаны путем сочетания результатов предыдущего исследования, выполненного при систематическом обзоре литературы, с обширной оценкой программы целенаправленного наблюдения в Квинсленде, Австралия.

Результаты: Имеются следующие рекомендации. Дети с факторами риска семейной истории или с черепно- лицевыми пороками должны проходить проверку слуха, дети с фактором риска низкого веса во время рождения - нет. Дети с фактором риска синдрома или продолжительных дыхательных расстройств потенциально должны проходить проверку слуха; однако решающие доказательства не получены. Также дети с с факторами риска бактериального менингита и гипербилирубинемии потенциально могут не требовать проверки слуха, но, снова, решающие доказательства не получены. При факторе риска тяжелой асфиксии и врожденной инфекции, доказательства были нерешающими и/или противоречивыми, поэтому никаких рекомендаций не имеется.

Заключение: Для дальнейших информационных, основанных на доказательствах, клинических рекомендаций по выявлению потери слуха в раннем детстве требуется больше исследований.

Ключевые слова: наблюдение • факторы риска • из группы риска • проверка • постнатальная потеря слуха • дети

Сокращения: ABR - слуховой стволомозговой ответ; CMV - цитомегаловирус; DPOAEs - отоакустические эмиссии на частоте продукта искажения; ЕСМО - экстракорпоральная мембранная оксигенация; НIЕ - гипоксическая ишемическая энцефалопатия; ВИЧ - вирус иммунодефицита человека; HVDT - слуховой тест по определению места происхождения звука; JCIH - комитет по проблемам слуха у грудных детей; LBW - низкий вес при рождении; NHMRC - Совет национального здравоохранения и медицинских исследований (Австралия); РPHN - легочная гипертензия при системной склеродермии новорожденного; TEOAЕs - методы вызванной задержанной отоакустической эмиссии; UNHS - всеобщее тестирование слуха новорожденных; VRA - аудиометрия с визуальным подкреплением. 


\section{Background}

The Joint Committee on Infant Hearing (JCIH) of the American Academy of Pediatrics recommends targeted surveillance as the primary method to monitor hearing in children who may be at risk of developing a postnatal hearing loss [1]. The most recent guidelines outlined in the JCIH 2007 Position Statement identified 11 risk factor categories associated with hearing loss, and any child that presents with one of these factors during universal newborn hearing screening (UNHS) or in the medical home during early well-infant visits should have at least one audiological assessment by 24 to 36 months of age. On the JCIH risk factor registry, eight individual risk factors are marked as a greater concern for delayed-onset hearing loss. These include caregiver concerns, family history, extracorporeal membrane oxygenation (ECMO), cytomegalovirus (CMV), syndromes associated with progressive hearing loss, neurodegenerative disorders, culture-positive postnatal infections associated with sensorineural hearing loss, and chemotherapy. It is recommended that any child that presents with one of these risk factors have more frequent audiological assessments throughout early childhood. In addition to risk factor monitoring, the JCIH recommends the family doctor monitor auditory skills, developmental milestones, and middle ear status in all children and should consider caregiver concerns about the child's speech and language abilities.

Although these recommendations are proposed by the $\mathrm{JCIH}$, many targeted surveillance programs are only loosely basing their programs on these recommendations due to significant criticisms against risk factor registries. Criticisms associated with targeted surveillance programs include the lack of evidence for the majority of the risk factors on the JCIH registry in detecting postnatal hearing loss [2], the large number of children without risk factors who develop a postnatal hearing loss $[3,4]$, the lack of parental co-operation in providing risk factors and attending appointments $[5,6]$, and the difficulties in behaviourally identifying hearing loss in young children $[7,8]$. As many programs are failing to abide by the JCIH recommendations, there is a lack of consistency across targeted surveillance programs in regards to risk factors used and frequency of audiology appointments [2].

This article is the final in a series of four publications which have addressed the evidence for targeted surveillance programs using a risk factor registry. The outcomes of the previous three studies are combined in this publication to arrive at formal recommendations for risk factor registries.

The first study in the series [2] was a systematic literature review that investigated the literature for evidence-based support for targeted surveillance programs using a risk factor registry. The literature search was conducted in the databases of Medline, CINAHL, and EMBASE, with relevant publications from 1973 to March 2011 accessed so that the changing processes and techniques for detecting postnatal hearing loss would be adequately represented. Reference lists of key publications and expert committee papers were also inspected for any additional publications. In total, 40 articles met the inclusion criteria and were included in the review. Outcomes of the review revealed that CMV, ECMO, congenital diaphragmatic hernia, and persistent pulmonary hypertension of the newborn were associated with postnatal hearing loss, whereas preauricular skin tags and ear pits, low birth weight (LBW), and toxoplasmosis were not. The review also identified that second-phase universal screening programs, CMV screening, and genetic screening should be explored as potential additions or alternatives to targeted surveillance using risk factors. It was also noted that the conclusions drawn from the review should be treated with caution as many of the publications included small sample sizes and were mainly based at a single site only. Overall, this study highlighted the significant gaps in the literature for risk factors and postnatal hearing loss and emphasised the need for further research in this area.

The second study [9] was an evaluation of a targeted surveillance program using a risk factor registry that is currently operating in Queensland, Australia. The UNHS and targeted surveillance program was introduced to Queensland in September 2004, with full implementation achieved by December 2006. The risk factors incorporated in the UNHS and targeted surveillance program in Queensland are given in Table 1. Most children referred for targeted surveillance are seen at audiology for a one-off appointment at 9 to 12 months old with the exception of children who have family history or congenital infection as a risk factor. Children with family history as a risk factor are seen at 6 months old, then every 6 months until 2 years old, with a discharge assessment performed at 3 years old. Children with congenital infection as a risk factor are seen at 3 months old, 6 months old, and then every 6 months until 2 years old. Assessments performed at these appointments depend on the child's age and developmental level and include otoscopy, tympanometry, auditory brainstem response (ABR), visual reinforcement audiometry (VRA), transient evoked otoacoustic emissions (TEOAEs), distortion product otoacoustic emissions (DPOAEs), and play audiometry. Children are discharged from the targeted surveillance program when they have completed their appointment series and frequency-specific information has been obtained for each ear. For the study period of September 2004 to December $2009,7,320$ children $(2.8 \%$ of 261,328$)$ were referred to the targeted surveillance program, of which $56(0.77 \%)$ were identified with a postnatal hearing loss. The risk factors present in the children referred for targeted surveillance as well as those who developed a postnatal hearing loss are given in Table 2. For the children referred for targeted surveillance, the largest proportion of referrals were generated from family history (40.5\%), LBW (31.6\%), and prolonged ventilation (25.0\%). For the risk factors reported in children who developed a postnatal hearing loss, $46.4 \%$ reported family history as a risk factor, and $19.6 \%$ reported a syndrome or prolonged ventilation as a risk factor.

Another major finding of this study was the high 'lost contact' rate of $32.4 \%$ reported for the surveillance program. Investigation of risk factors present in children who did not attend revealed that children with one risk factor were significantly more likely to not attend a surveillance appointment $\left[\chi^{2}(1)=29.4, p<0.001\right]$ when compared to children with more than one risk factor. Investigation of risk factors in these children revealed that children with the risk factors of family history $\left[\chi^{2}(1)=33.9, p<0.001\right]$ and congenital infection $\left[\chi^{2}(1)=4.3, p=0.037\right]$ were significantly overrepresented in the lost contact cohort when compared to 
Table 1. Risk factor registry used by Queensland's universal newborn hearing screening (UNHS) and targeted surveillance program [10].

\begin{tabular}{cl}
\hline 1 & $\begin{array}{l}\text { Family history of permanent childhood hearing loss (mother/father/siblings of baby only) excluding } \\
\text { grommets/ear infections/trauma }\end{array}$ \\
\hline 2 & Syndromes associated with hearing loss (e.g., Down syndrome, FAS) \\
\hline 3 & Prolonged ventilation $\geq 5$ days (IPPV/CPAP) \\
\hline 4 & Bacterial meningitis (confirmed/suspected) \\
\hline 5 & Low birth weight $\leq 1500$ grams \\
\hline 6 & Severe asphyxia at birth (convulsions/HIE/PPHN) \\
\hline 7 & Craniofacial anomalies (e.g., cleft palate - excluding cleft lip and skin tags) \\
\hline 9 & Hyperbilirubinemia levels $\geq 450 \mu$ mol/L (term) or $\geq 340 \mu$ mol/L (preterm) \\
\hline 10 & Proven/suspected congenital infection of the baby (toxoplasmosis, rubella, CMV, herpes, syphilis) \\
\hline
\end{tabular}

FAS - fetal alcohol syndrome; IPPV - intermittent positive pressure ventilation; CPAP - continuous positive airway pressure; HIE - hypoxic ischemic encephalopathy; PPHN - persistent pulmonary hypertension of the newborn; CMV - cytomegalovirus.

Table 2. Risk factors present in all children enrolled for targeted surveillance, children who developed a postnatal hearing loss, and children who became 'lost contact' [9].

\begin{tabular}{|c|c|c|c|c|}
\hline $\begin{array}{l}\text { Individual } \\
\text { risk factors }\end{array}$ & $\begin{array}{c}\text { Referrals for targeted } \\
\text { surveillance } \\
n=7320\end{array}$ & $\begin{array}{c}\text { Postnatal } \\
\text { hearing loss } \\
n=56\end{array}$ & $\begin{array}{c}\text { Risk factors in } \\
\text { children with one } \\
\text { risk factor only } \\
n=5659\end{array}$ & $\begin{array}{l}\text { Risk factors in } \\
\text { children with one } \\
\text { risk factor only who } \\
\text { became 'lost contact' } \\
n=1360\end{array}$ \\
\hline Family history & 2968 (40.5\%) & $26(46.4 \%)$ & 2831 (50.0\%) & 774 (56.9\%) \\
\hline Syndrome & $353 \quad(4.8 \%)$ & 11 (19.6\%) & $259 \quad(4.6 \%)$ & $27 \quad(2.0 \%)$ \\
\hline Prolonged ventilation & 1833 (25.0\%) & 11 (19.6\%) & $398 \quad(7.0 \%)$ & $82 \quad(6.0 \%)$ \\
\hline Bacterial meningitis & $68 \quad(0.9 \%)$ & $0 \quad(0 \%)$ & $41 \quad(0.7 \%)$ & $2 \quad(0.2 \%)$ \\
\hline Low birth weight & 2310 (31.6\%) & $4 \quad(7.1 \%)$ & $948 \quad(16.8 \%)$ & 235 (17.3\%) \\
\hline Severe asphyxia & $591 \quad(8.1 \%)$ & 9 (16.1\%) & $353 \quad(6.3 \%)$ & $70 \quad(5.2 \%)$ \\
\hline Craniofacial anomalies & $588 \quad(8.0 \%)$ & $10(17.9 \%)$ & $(5.6 \%)$ & $56 \quad(4.1 \%)$ \\
\hline Hyperbilirubinemia & $334 \quad(4.6 \%)$ & $2 \quad(3.6 \%)$ & $(4.7 \%)$ & $52 \quad(3.8 \%)$ \\
\hline Congenital infection & $244 \quad(3.3 \%)$ & $2 \quad(3.6 \%)$ & $(3.0 \%)$ & $52 \quad(3.8 \%)$ \\
\hline Professional concern & $78 \quad(1.1 \%)$ & $(0 \%)$ & $74 \quad(1.3 \%)$ & $10 \quad(0.7 \%)$ \\
\hline
\end{tabular}

children originally referred with these risk factors (e.g., family history constituted $50.0 \%$ of the original referrals in children with one risk factor but $56.9 \%$ of the lost contact cohort) (see Table 2). Although findings from this program evaluation indicated that the targeted surveillance program was successful in detecting postnatal hearing loss, the high lost contact rates, the significant number of children with on-going monitoring appointments, the delays in first assessment, and the extensive diagnostic testing undertaken for all children referred for targeted surveillance questioned the effectiveness of risk factor monitoring.

The third study [10] used a subset of the cohort from the second study and focused primarily on the risk factors in children who had completed their appointment series according to Queensland Health protocol and were discharged from the targeted surveillance program. The goal of this study was to investigate the risk factors that were most likely to predict the occurrence of postnatal hearing loss using a formal analysis. Major outcomes of this study were that the risk factors of family history and craniofacial anomalies predicted the occurrence of postnatal hearing loss, whereas LBW did not.

The purpose of the current paper is to provide recommendations for risk factor registries incorporated within targeted surveillance programs using the information derived from the previous three studies. By combining the 
Table 3. Levels of evidence for recommendations based on the Australian National Health and Medical Research Council (NHMRC) levels of evidence [11].

\begin{tabular}{|c|c|c|}
\hline Grade & Recommendation & Description \\
\hline$A$ & Monitor & $\begin{array}{l}\text { Collective evidence generally offers strong support for monitoring. } \\
\text { For example, existence of cohort studies indicating cases of postnatal } \\
\text { hearing loss in children with the risk factor in isolation }+ \text { a positive yield } \\
+ \text { positive relationship/significant Chi-squared correlation }+ \text { OR>1 }\end{array}$ \\
\hline B & Potentially Monitor & $\begin{array}{l}\text { Overall findings are mixed; however, some or most indicate support for } \\
\text { monitoring as per grading A }\end{array}$ \\
\hline C & Lack of Evidence & $\begin{array}{l}\text { Collective evidence is lacking. For example, no literature evidence or } \\
\text { case studies only; +/- presence of complicating risk factors; and/or } \\
\text { logistic regression not completed. Alternatively, overall findings may be } \\
\text { highly mixed/inconclusive }\end{array}$ \\
\hline $\mathrm{D}$ & Potentially Don't Monitor & $\begin{array}{l}\text { Overall findings are mixed; however, some or most indicate support for } \\
\text { not monitoring as per grading E }\end{array}$ \\
\hline$E$ & Don't Monitor & $\begin{array}{l}\text { Collective evidence generally offers strong support for not monitoring. } \\
\text { For example, existence of cohort studies indicating no/limited cases of } \\
\text { postnatal hearing loss and complicating risk factors present + nil yield } \\
+ \text { negative relationship/insignificant Chi-squared correlation }+ \text { OR } \leq 1\end{array}$ \\
\hline
\end{tabular}

information obtained from these studies, a better understanding of the relationship between risk factors and postnatal hearing loss can occur, which will help inform evidence-based, clinical policy recommendations for hearing loss surveillance in infants transnationally and beyond.

\section{Recommendations for risk factors incorporated in a risk factor registry}

Listed below are recommendations supporting or opposing monitoring, within a targeted surveillance program, of children who have each risk factor. Each recommendation is given an overall grading based on the available evidence (see Table 3 ). This grading system was based on the Australian National Health and Medical Research Council (NHMRC) levels of evidence and grades of recommendation [11]. In general, where the evidence is clear and in favour of monitoring, the recommendation is scored as 'Grade A: Monitor'. Grade A recommendations are worded to include the word "should" to indicate that monitoring of children with this risk factor should occur. When the collective evidence provides support for not monitoring a particular risk factor, the recommendation is scored as 'Grade E: Don't Monitor' and the wording in the recommendation is "should not". For recommendations graded as B and D, the evidence is less clear and this is reflected in the wording of the recommendation, i.e., 'Potentially Monitor' and 'Potentially Don't Monitor'. Where there is a lack of evidence or mixed/inconclusive evidence to support or oppose monitoring, the recommendation is scored as 'Grade C: Lack of Evidence.' Currently, there is only sufficient support to recommend monitoring for risk factors graded A and B only.

Family history of permanent childhood hearing loss (mother/father/siblings of baby only) excluding grommets/ear infections/trauma

Outcomes of the systematic literature review: The systematic literature review revealed three studies [12-14] that reported on children with postnatal hearing loss and family history as a risk factor. However, the evidence provided by these studies was insufficient as it was difficult to establish the exact nature of the relationship between family history and the advent of postnatal hearing loss given that: (i) children with a hearing loss only were included (i.e., children without postnatal hearing loss were not included); or (ii) the children who developed a postnatal hearing loss had more than one risk factor.

Outcomes of the analysis of Queensland's targeted surveillance program: Analysis of Queensland's targeted surveillance program provided support in favor of monitoring children with family history as a risk factor. Family history was the most frequently reported risk factor in children with a postnatal hearing loss, with $46.4 \%(26 / 56)$ of children having this risk factor. A positive yield of 5.3\% (26/494) was calculated for children with family history who had completed their appointment series. Further formal analysis on these children revealed a positive significant correlation between family history and postnatal hearing $\left[\chi^{2}(1)=16.9, p<0.001\right]$. Logistic regression analysis was also completed and revealed that children with family history as a risk factor were almost twice more likely to develop a postnatal hearing loss than those without family history as a risk factor (OR: 1.92; 95\% CI: 1.04-3.56).

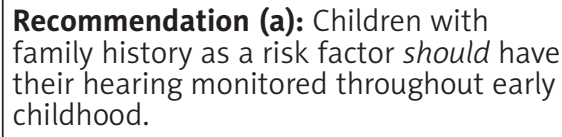

Grade A: Monitor

Syndromes associated with hearing loss (e.g., Down, fetal alcohol syndrome)

Outcomes of the systematic literature review: Limited evidence was obtained from the systematic literature review for syndromes and postnatal hearing loss, with only one child identified with the risk factor of syndrome who passed newborn hearing screening who subsequently developed a postnatal hearing loss. This child had Branchio-oto-renal syndrome as well as preauricular skin tags and pits [15]. 
Outcomes of the analysis of Queensland's targeted surveillance program: The outcomes of the analysis of Queensland's targeted surveillance program indicated promising results in favor of monitoring children with a syndrome. For children diagnosed with a postnatal hearing loss, $19.6 \%$ $(11 / 56)$ had syndrome as a risk factor. Syndrome had the highest yield calculation of all the risk factors, with $12.0 \%$ (11/92) of children with a syndrome who had completed their appointment series having developed a postnatal hearing loss. Results from chi-squared analysis revealed a positive significant correlation between syndrome and postnatal hearing loss $\left[\chi^{2}(1)=32.2, p<0.001\right]$. Further analysis using logistic regression was unable to be completed due to issues of multicollinarity with craniofacial anomalies.

\begin{tabular}{|l|l|}
\hline $\begin{array}{l}\text { Recommendation (b): Children with } \\
\text { syndrome as a risk factor should potentially } \\
\text { have their hearing monitored throughout } \\
\text { early childhood. }\end{array}$ & $\begin{array}{l}\text { Prade B: } \\
\text { Monitor }\end{array}$ \\
\hline
\end{tabular}

Prolonged ventilation $\geq 5$ days

Outcomes of the systematic literature review: Although the systematic literature review identified several studies that reported on children with postnatal hearing loss who had received ventilation, it was difficult to establish the exact nature of the relationship between ventilation and postnatal hearing loss given that the children with postnatal hearing loss had other complicating risk factors. Other risk factors present in these children include respiratory distress syndrome [16,17], congenital diaphragmatic hernia [18], asphyxia [13], and family history $[12,13]$.

The systematic literature review also identified five publications on children who had received ECMO and developed a postnatal hearing loss. ECMO is often used post cardiac surgery when all other forms of conventional ventilation have failed. Four of the five studies reported similar findings, with $8.1 \%$ [19] to $12.6 \%$ [20] of the cohort who had received ECMO developing a postnatal hearing loss.

Outcomes of the analysis of Queensland's targeted surveillance program: Analysis of Queensland's targeted surveillance program indicated promising results in favor of monitoring children, with $19.6 \%$ (11/56) of children with a postnatal hearing loss having prolonged ventilation as a risk factor. The yield calculation for children with the risk factor prolonged ventilation who had completed their appointment series was $1.5 \%$ (11/738). Results from chi-squared analysis revealed a significant correlation between prolonged ventilation and postnatal hearing loss $\left[\chi^{2}(1)=6.0, p=0.014\right]$. Further analysis on the risk factor prolonged ventilation was unable to be completed due to issues of multicollinarity with LBW.

At the time of this study, ECMO was not performed in Queensland.

\begin{tabular}{|l|l|}
\hline Recommendation (c): Children with & Grade B: \\
prolonged ventilation as a risk factor & Potentially \\
should potentially have their hearing & Monitor \\
monitored throughout early childhood. & \\
In addition to prolonged ventilation, if & \\
ECMO is used then the child should have & \\
their hearing monitored throughout early & \\
childhood. & \\
\hline
\end{tabular}

\section{Bacterial meningitis (confirmed/suspected)}

Outcomes of the systematic literature review: The inclusion criteria for studies in the systematic literature review were that the neonates needed to have passed newborn hearing screening/audiology assessment at birth and that risk factor/s needed to be reported during the newborn hearing screening period (birth through age 28 days consistent with the JCIH guidelines). These criteria were used, since the literature review was designed to examine the evidence for targeted surveillance using a risk factor registry in detecting postnatal hearing loss. As a result of these criteria, a substantial amount of literature associated with bacterial meningitis was eliminated from the systematic literature review. For the two studies included in the systematic literature review which had cases of children with bacterial meningitis who developed a postnatal hearing loss $[13,14]$, it was difficult to establish the exact nature of the relationship between bacterial meningitis and postnatal hearing loss given that only children with a hearing loss were included in the study and additional risk factors were present in these cases.

Outcomes of the analysis of Queensland's targeted surveillance program: Information obtained from analysis of Queensland's targeted surveillance program was also limited. For the 68 children referred for targeted surveillance with bacterial meningitis identified at the birth screen, no children were identified with a postnatal hearing loss (nil yield). Further, no significant correlation was found between postnatal hearing loss and bacterial meningitis. Analysis of cases of postnatal hearing loss that were incidentally identified and reported to the Healthy Hearing program revealed that two children developed a hearing loss subsequent to bacterial meningitis during childhood. These children were assessed as a result of a medical referral rather than through the targeted surveillance program as they contracted bacterial meningitis following the newborn hearing screening period. Therefore, these cases of postnatal hearing loss were excluded from the analysis of the targeted surveillance program.

\begin{tabular}{|l|l|}
\hline Recommendation (d): Children with & Grade D: \\
bacterial meningitis as a risk factor & Potentially \\
identified during the newborn hearing & Don't \\
screening period should potentially not \\
have their hearing monitored throughout \\
early childhood.
\end{tabular}

\section{Low birth weight (LBW) $(\leq 1500 \mathrm{~g})$}

Outcomes of the systematic literature review: One high quality cohort study was identified in the systematic literature review which monitored hearing in children with LBW [21]. Of the 224 children included in this study, six (2.7\%) developed a postnatal hearing loss. All six children had other contributing risk factors including the administration of aminoglycosides. Therefore, the development of the hearing loss may be a result of the other risk factors and not LBW.

Outcomes of the analysis of Queensland's targeted surveillance program: Analysis of Queensland's targeted surveillance program provided evidence against monitoring 
children with LBW as a risk factor. Of the children identified with a postnatal hearing loss, $7.1 \%(4 / 56)$ had LBW as a risk factor. However, yield calculations for children with LBW who had completed their appointment series was only $0.4 \%$ (4/905). One of these four children developed a permanent conductive hearing loss following recurrent otitis media. Formal analysis using chi-squared revealed a significant negative relationship between LBW and postnatal hearing loss. Further analysis using logistic regression analysis revealed that children with LBW as a risk factor were one-tenth more likely to develop a postnatal hearing loss than those with normal birth weight (>1500 g) (OR: 0.14; 95\% CI: 0.05-0.39).

Recommendation (e): Children with LBW as Grade E: a risk factor should not have their hearing Don't monitored throughout early childhood.

Monitor

Severe asphyxia at birth [convulsions/ hypoxic ischemic encephalopathy (HIE)/ persistent pulmonary hypertension of the newborn (PPHN)]

Outcomes of the systematic literature review: One high quality cohort study was identified in the systematic literature review that monitored hearing in children with PPHN [22]. Of the 40 children included in the study, four (10\%) developed a postnatal hearing loss. Several other studies were also identified that reported on children with severe asphyxia who developed a postnatal hearing loss. However, predominantly these were case studies only, with the majority of children with severe asphyxia who developed a postnatal hearing loss having other contributing risk factors [13,14,23-25].

Outcomes of the analysis of Queensland's targeted surveillance program: Evidence provided from analysis of Queensland's targeted surveillance program was inconclusive. For children diagnosed with a postnatal hearing loss, $16.1 \%(9 / 56)$ had severe asphyxia as a risk factor. Although yield of postnatal hearing loss in children with severe asphyxia who had completed their surveillance appointments was $4.1 \%(9 / 217)$, there was no significant correlation found between severe asphyxia and postnatal hearing loss on further formal analysis.

Recommendation (f): There is insufficient evidence to support or oppose monitoring hearing in children with severe asphyxia.

Grade C: Lack of Evidence

Craniofacial anomalies e.g., cleft palate (excluding cleft lips and skin tags)

Outcomes of the systematic literature review: Two studies were identified in the systematic literature review that addressed the risk factor of craniofacial anomalies. The first study [14] reported that two of 23 children (8.7\%) with a postnatal hearing loss had craniofacial anomalies as a risk factor. The second study [15] examined hearing loss in children with preauricular skin tags and pits in isolation and in combination with other risk factors. From the 637 children included in this study, one child $(0.2 \%)$ developed a postnatal hearing loss. This child also had Branchio-oto-renal syndrome in addition to preauricular skin tags and pits. The authors recommended that children with preauricular skin tags and pits in isolation do not need to have their hearing monitored throughout early childhood.

Outcomes of the analysis of Queensland's targeted surveillance program: Analysis of Queensland's targeted surveillance program provided support in favor of monitoring children with craniofacial anomalies. For children diagnosed with a postnatal hearing loss, $17.9 \%(10 / 56)$ had craniofacial anomalies as a risk factor. Yield calculations for children who had completed their appointment series was $5.2 \%(10 / 191)$. Further analysis of these children revealed a positive significant correlation between craniofacial anomalies and postnatal hearing loss $\left[\chi^{2}(1)=5.4\right.$, $p=0.020]$. Logistic regression analysis also revealed that children with craniofacial anomalies were more than two times more likely to develop a postnatal hearing loss than those without craniofacial anomalies (OR: 2.61; 95\% CI: 1.19-5.70).

\section{Recommendation (g): Children with}

craniofacial anomalies (excluding ear pits

and skin tags) as a risk factor should have

their hearing monitored throughout early

childhood.

Hyperbilirubinemia levels $\geq 450 \mu \mathrm{mol} / \mathrm{L}$ (term) or $\geq 340 \mu \mathrm{mol} / \mathrm{L}$ (preterm)

Outcomes of the systematic literature review: One case report only was identified through the systematic literature review on a child with hyperbilirubinemia who developed a postnatal hearing loss [13]. This child had other contributing risk factors including family history. Therefore, the development of postnatal hearing loss cannot solely be attributed to hyperbilirubinemia.

Outcomes of the analysis of Queensland's targeted surveillance program: There was limited evidence provided by analysis of Queensland's targeted surveillance program, with $3.6 \%(2 / 56)$ of children with a postnatal hearing loss having hyperbilirubinemia as a risk factor. Yield was calculated at $1.4 \%(2 / 147)$ for children who had completed their appointment series only. There was no significant correlation found between hyperbilirubinemia and postnatal hearing loss on further formal analysis.

\begin{tabular}{|l|l|}
\hline $\begin{array}{l}\text { Recommendation (h): Children with } \\
\text { hyperbilirubinemia as a risk factor } \\
\text { should potentially not have their hearing } \\
\text { monitored throughout early childhood. }\end{array}$ & $\begin{array}{l}\text { Grade D: } \\
\text { Potentially } \\
\text { Don't } \\
\text { Monitor }\end{array}$ \\
\hline
\end{tabular}

Proven/suspected congenital infection of the baby (toxoplasmosis, rubella, CMV, herpes, syphilis)

Outcomes of the systematic literature review: Results from the systematic literature review revealed information on the congenital infections of CMV and toxoplasmosis only. For CMV, studies reported on children who were either asymptomatic, symptomatic, or both, and a range of results for the proportion of the cohort who developed a postnatal hearing loss was identified. For children with asymptomatic CMV, the proportion that developed a postnatal hearing loss ranged from $1.3 \%$ [26] to 
$5.6 \%$ [27] of the cohort. For children with symptomatic $\mathrm{CMV}$ who developed a postnatal hearing loss, the proportion ranged from $5.7 \%$ [28] to $14.4 \%$ [29] of the cohort.

For toxoplasmosis, the literature search identified a systematic literature review [30] that addressed toxoplasmosis exposure and sensorineural hearing loss. The outcomes of this study found that there was no evidence associating neonatal toxoplasmosis with postnatal hearing loss.

Outcomes of the analysis of Queensland's targeted surveillance program: Limited evidence was provided by analysis of the targeted surveillance program in Queensland. For children identified with a postnatal hearing loss, 3.6\% $(2 / 56)$ had congenital infection as a risk factor. The yield calculation for children with the risk factor congenital infection who had completed their appointment series was 3.7\% (2/54). Despite congenital infection having had a notable yield of children developing a postnatal hearing loss, there was no significant correlation found between this risk factor and postnatal hearing loss on further statistical analysis.

\begin{tabular}{|l|l|}
\hline $\begin{array}{l}\text { Recommendation (i): Within the risk factor } \\
\text { of congenital infection, children with CMV }\end{array}$ & $\begin{array}{l}\text { Grade C: } \\
\text { Lack of }\end{array}$ \\
as a risk factor should have their hearing & Evidence \\
monitored throughout early childhood; and & \\
children with toxoplasmosis as a risk factor & \\
should not have their hearing monitored & \\
throughout early childhood. There is & \\
insufficient evidence to support or oppose & \\
monitoring hearing in children with rubella, & \\
herpes, or syphilis. & \\
\hline
\end{tabular}

\section{Professional concern}

Outcomes of the systematic literature review: The general risk factor 'professional concern' has not been explicitly reported on in the literature. However, there are other risk factors that may be incorporated under the umbrella of professional concern which have been reported. Examples of these other risk factors include cerebral hemorrhage, ototoxic therapy, and gestational age of $<33$ weeks $[13,14,18]$. However, as these cases were drawn from studies which reported on children with hearing loss only as well as children with other complex risk factors, it was difficult to establish the exact relationship between these risk factors and postnatal hearing loss.

Outcomes of the analysis of Queensland's targeted surveillance program: The risk factor 'professional concern' is used in Queensland to encompass medical conditions that present between birth and 28 days, are not appropriate for the other risk factor categories, and where the treating doctor has concerns for the child's hearing. Professional concern covers a broad range of medical issues including chemotherapy or human immunodeficiency virus (HIV) during pregnancy. For the 78 children referred to the targeted surveillance program with the risk factor of professional concern, no children (nil yield) had developed a postnatal hearing loss. No significant correlation was found on further analysis between postnatal hearing loss and professional concern.
Recommendation (j): Children with professional concern as a risk factor identified during the newborn hearing screening period should potentially not have their hearing monitored throughout early childhood.

\section{Directions for future research}

This research has identified significant gaps in the current literature which need further investigation. Particularly, it has emphasised the need for further research in order to firmly establish the relationship between risk factors and postnatal hearing loss. Of the above risk factors, there was convincing evidence for recommendations for only three. Children with family history and craniofacial anomalies as a risk factor should have their hearing monitored (Grade A) and children with LBW as a risk factor should not (Grade E). Although there was some evidence to suggest that children with syndrome or prolonged ventilation as a risk factor may potentially require monitoring (Grade B), there is currently insufficient evidence to draw definitive conclusions regarding this recommendation. Similarly, the current evidence for bacterial meningitis, hyperbilirubinemia, and professional concern leans towards potentially not monitoring (Grade D); however, again the evidence is lacking and not conclusive. Current research on the risk factors of severe asphyxia and congenital infection is inconclusive and/or conflicting with no conclusions able to be drawn (Grade C). In general, there is a lack of large cohort studies that follow children with an individual risk factor to determine the likelihood of such children developing a postnatal hearing loss.

Another area which requires investigation is the suitability of risk factor monitoring compared to other post-neonatal care pathways that may be more effective in detecting postnatal hearing loss. Other post-neonatal care pathways that could be used in conjunction with, or instead of, risk factor monitoring include introducing neonatal CMV and/or genetic screening, universal preschool and school screening programs, referral for an assessment due to parent/professional concerns, and the health visitor distraction test (HVDT) $[2,9,31,32]$. Although these assessment pathways have been reported in the literature, to date there has been no study that has compared the use of these alternative models to risk factor monitoring. To establish the most effective way to detect postnatal hearing loss in early childhood, further large-scale longitudinal studies are required which assess children both with and without risk factors.

\section{Summary and Conclusion}

This study has listed recommendations for inclusion/exclusion of risk factors to be incorporated within risk factor registries used by targeted surveillance programs. Convincing evidence was found for three risk factors only. The risk factors of family history and craniofacial anomalies should be included in a risk factor registry and children with these risk factors should have their hearing monitored throughout early childhood. In contrast, the risk factor of LBW should not be incorporated in a risk factor registry and children with LBW in isolation do not need to have their hearing monitored. Children with the risk factors 
of syndrome and prolonged ventilation should potentially have their hearing monitored, although the evidence is not definitive. Equally, children with the risk factors of bacterial meningitis, hyperbilirubinemia, and professional concern may not need to have their hearing monitored; however, again the evidence is not definitive. The evidence for severe asphyxia and congenital infection is inconclusive and/or conflicting. Therefore, no recommendations are made for monitoring children with these risk factors. Although this paper has presented recommendations for risk factor registries, further large-scale, population-based research should be conducted on children both with and without risk factors to establish the most effective way of detecting postnatal hearing loss in childhood.

\section{References:}

1. JCIH (American Academy of Pediatrics). Year 2007 position statement: principles and guidelines for early hearing detection and intervention programs. Pediatrics, 2007; 120(4): 898-921

2. Beswick R, Driscoll C, Kei J: Monitoring for postnatal hearing loss using risk factors: a systematic literature review. Ear Hear, 2012a [in press]

3. Kennedy C, Kimm L, Cafarelli Dees D et al: Controlled trial of universal neonatal screening for early identification of permanent childhood hearing impairment. Wessex Universal Neonatal Hearing Screening Trial Group. Lancet, 1998; 352(9145): 1957-64

4. Mehl AL, Thomson V: The Colorado newborn hearing screening project, 1992-1999: on the threshold of effective population-based universal newborn hearing screening. Pediatrics, 2002; 109(1): E7

5. Hutt N, Rhodes C: Post-natal hearing loss in universal neonatal hearing screening communities: current limitations and future directions. J Paediatr Child Health, 2008; 44(3): 87-91

6. Northern J, Downs M: Hearing in children. $5^{\text {th }}$ ed. Philadelphia: Lippincott Williams \& Wilkins, 2002

7. Watkin PM, Baldwin M, Laoide S: Parental suspicion and identification of hearing impairment. Arch Dis Child, 1990; 65(8): 846-50

8. Watkin PM, Hasan J, Baldwin M, Ahmed M: Neonatal hearing screening: have we taken the right road? Results from a 10-year targeted screen longitudinally followed up in a single district. Audiological Medicine, 2005; 3: 175-84

9. Beswick R, Driscoll C, Kei J, Glennon S: Targeted surveillance for postnatal hearing loss: a program evaluation. Int J Pediatr Otorhinolaryngol, 2012b; 78: 1046-56

10. Beswick R, Driscoll C, Kei J et al: Which risk factors predict postnatal hearing loss in children? J Am Acad Audiol, 2012c [in press]

11. National Health and Medical Research Council. NHMRC levels of evidence and grades for recommendations for developers of guidelines: Australian Government, 2009

12. Robertson CMT, Howarth TM, Bork DLR, Dinu IA: Permanent bilateral sensory and neural hearing loss of children after neonatal intensive care because of extreme prematurity: a thirty-year study. Pediatrics, 2009; 123(5): e797-807

13. Thiringer K, Kankkunen A, Liden G, Niklasson A: Perinatal risk factors in the aetiology of hearing loss in preschool children. Dev Med Child Neurol, 1984; 26(6): 799-807

14. Weichbold V, Nekahm-Heis D, Welzl-Mueller K: Universal newborn hearing screening and postnatal hearing loss. Pediatrics, 2006; 117(4): e631-36

15. Roth DA, Hildesheimer M, Bardenstein S et al: Preauricular skin tags and ear pits are associated with permanent hearing impairment in newborns. Pediatrics; 2008; 122(4): e884-90

16. Borradori C, Fawer CL, Buclin T, Calame A: Risk factors of sensorineural hearing loss in preterm infants. Biol Neonate, 1997; 71(1): 1-10
17. Konkle DF, Knightly CA: Delayed-onset hearing loss in respiratory distress syndrome: case reports. J Am Acad Audiol, 1993; 4(6): 351-54

18. Masumoto K, Nagata K, Uesugi T et al: Risk factors for sensorineural hearing loss in survivors with severe congenital diaphragmatic hernia. Eur J Pediatr, 2007; 166(6): 607-12

19. Mann T, Adams K: Sensorineural hearing loss in ECMO survivors. Extracorporeal membraneous oxygenation. J Am Acad Audiol, 1998; 9(5): 367-70

20. Fligor BJ, Neault MW, Mullen CH et al: Factors associated with sensorineural hearing loss among survivors of extracorporeal membrane oxygenation therapy. Pediatrics, 2005; 115(6): 1519-28

21. Salamy A, Eldredge L, Tooley WH: Neonatal status and hearing loss in high-risk infants. J Pediatr, 1989; 114(5): 847-52

22. Hendricks-Munoz KD, Walton JP: Hearing loss in infants with persistent fetal circulation. Pediatrics, 1988; 81(5): 650-56

23. Hutchin ME, Gilmer C, Yarbrough WG: Delayed-onset sensorineural hearing loss in a 3-year-old survivor of persistent pulmonary hypertension of the newborn. Arch Otolaryngol Head Neck Surg, 2000; 126(8): 1014-17

24. Kawashiro N, Tsuchihashi N, Koga K et al: Delayed post-neonatal intensive care unit hearing disturbance. Int J Pediatr Otorhinolaryngol, 1996; 34(1-2): 35-43

25. Lasky RE, Wiorek L, Becker TR: Hearing loss in survivors of neonatal extracorporeal membrane oxygenation (ECMO) therapy and high-frequency oscillatory (HFO) therapy. J Am Acad Audiol, 1998; 9(1): 47-58

26. Fowler KB, McCollister FP, Dahle AJ et al: Progressive and fluctuating sensorineural hearing loss in children with asymptomatic congenital cytomegalovirus infection. J Pediatr, 1997; 130(4): 624-30

27. Iwasaki S, Yamashita M, Maeda $\mathrm{M}$ et al: Audiological outcome of infants with congenital cytomegalovirus infection in a prospective study. Audiol Neurootol, 2007; 12(1): 31-36

28. Ross SA, Fowler KB, Ashrith G et al: Hearing loss in children with congenital cytomegalovirus infection born to mothers with pre-existing immunity. J Pediatr, 2006; 148(3): 332-36

29. Rivera LB, Boppana SB, Fowler KB et al: Predictors of hearing loss in children with symptomatic congenital cytomegalovirus infection. Pediatrics, 2002; 110(4): 762-67

30. Brown ED, Chau JK, Atashband S et al: A systematic review of neonatal toxoplasmosis exposure and sensorineural hearing loss. Int J Pediatr Otorhinolaryngol, 2009; 73(5): 707-11

31. Lü J, Huang Z, Yang T et al: Screening for delayed-onset hearing loss in preschool children who previously passed the newborn hearing screening. Int J Pediatr Otorhinolaryngol, 2011; 75(8): 1045-49

32. Watkin PM, Baldwin M: Identifying deafness in early childhood: requirements after the newborn hearing screen. Arch Dis Child, 2011; 96(1): 62-66 